\title{
Integrated Learning to Improve Creative Thinking Skills in Learning Media Course
}

\author{
Pudji Astuti, Sita Nurmasitah \\ Family Welfare Vocational Education Department, Engineering Faculty \\ Universitas Negeri Semarang \\ Semarang, Indonesia \\ pudjiastuti@mail.unnes.ac.id
}

\begin{abstract}
Education is a gateway to the achievement of the nation's ideals. Qualified education enables to produce reliable nation successors. There are many aspects related to qualified education, including learning activities. The challenges faced by education world are increasingly complex. In the industrial era 4.0, teachers should be able to motivate and improve students' creative thinking skills. Culinary Education Study Program in Department of Family Welfare Vocational Education as one of the LPTK must be able to provide prospective teachers in accordance with the development of industrial revolution 4.0. Creative thinking skills can be enhanced by a model of integrated learning activities among courses. The Learning Media Course is one of the courses in the curriculum of Culinary Education Study Program. The students are given the task of designing the learning media and applying it to other subjects they take as a presentation media. The observation was conducted according to the criteria of creative thinking skills.
\end{abstract}

Keywords-learning activities, learning media course, creative thinking skills

\section{INTRODUCTION}

It is in the hands of youth, the fate of the nation would be brought. These youth will soon become adult human beings who face a world full of challenges and problems and must be able to overcome them. The youth who become the future development, must be prepared to face the challenges and problems of life as well as to give the solution.

Countries that succeed in building a superior middle class society, able to reduce poverty, and lower the marginal society will have their economy increased. It requires creative human resources who are able to read challenges and opportunities and solve problems. The human resources are developed through education. Qualified education is very important to produce youth generation.

Based on IDI (Inclusive Growth and Development Index)'s data of 2017 on education and skills pillar, Indonesia is ranked 9 out of 34 countries, with a value of 4.79. This position shows that education in Indonesia has an upward trend, but not yet evenly distributed for all regions. Education in Indonesia has always been directed to advances although the results have not been satisfying, there are still areas experiencing teacher shortages and poorly running education. One of the provisions of teachers in regions, especially those regions with fewer teachers, is through SM3T program (Teaching Graduates in Frontier,
Outer, and Underdeveloped Areas) and is one form of improvement of education services.

The SM3T program is a program of educational graduate dedication to participate in the acceleration of educational development in the 3T (Frontier, Outer, and Underdeveloped Areas) for one year. The program is conducted as a preparation for professional educators who will be followed by the Professional Teacher Education program. The Government program will have professional teachers. Of course it must be prepared qualified graduates to join the government program for maximum results. This is done with learning activities at LPTK (Institute of Teachers' Education) which always improve the quality of learning activities. The running of the industrial revolution 4.0 also makes learning activities to adjust, so that will produce prospective teachers who have good communication, creative, and critical thinking.

Culinary Education Study Program is a study program that produces graduates which are in addition to competent in their field of study, culinary, also has the skills in teaching. The courses provided are in the form of practices and theories with student-centered learning activities. The methods include discussion/presentation and practice. The practice materials are done by practice in groups or independently.

Culinary Education Study Program is an educational institution that produces graduates as prospective teachers, in addition, knowledge and skills that can be mastered as an entrepreneurship capital. Graduates who will become teachers must join the SM3T and PPG (Teachers' Education Program) programs. This should be supported by maximum learning activities. Learning activities undertaken should be learning activities that enable students to communicate well, think critically and creatively which are essential in the era of revolution 4.0, so that they will be ready to become professional teachers.

\section{CREATIVE THINKING}

Creative thinking can achieve a goal effectively. According to Starbuck [1] and Hicks [2], creativity is no longer a monopoly by artists and musicians, but an important skill that everyone has to master. This means, creativity belongs to everyone, creativity can be taught, trained, and familiarized. Thus, creative thinking skills need to be done in the learning activities so that learners have creative thinking in facing challenges and solving problems. 
Creative learning, of course, can only be implemented by creative teachers and directly or indirectly will teach this creativity to the learners. Creative thinking is a capability that someone has. That ability will be reflected in one's behavior. Creative thinking is the ability to think consistently and continuously in an effort to produce something creative. This process does not necessarily always create a new concept, but the result can be something new resulting from the merger of two or more existing concepts. People who have creative thinking will have habits while the others have not, for example curousity, find problems, enjoy challenges, optimistic, see the problem as an opportunity, not easily give up, and try hard.

According to Munandar [3], creative thinking is to provide a variety of possible answers based on information provided with an emphasis on the diversity of numbers and conformity. Coleman and Hammen (Sukmadinata, 2004) [4] explain that creative thinking is a mental activity to improve the purity (originality), and the sharpness of understanding (insight) in developing something (generating).

According to Evans, Guilford and Torraance in Jazuli [5] stated that the characteristics of creative thinking namely:

a) Fluency, the ability to build many ideas. The more opportunities acquired, the more the chances to get good ideas.

b) Flexibility, the ability to build various ideas that is the ability to try different approaches in solving problems.

c) Originality, the ability to generate extraordinary ideas that are uncommon.

d) Problem sensitivity, the ability to recognize a problem or ignore the facts that are less related to recognize the real problem.

e) Elaboration, the ability to cut, develop or embellish ideas or products.

Indicators of the characteristics of creative thinking are manifested in attitudes and behaviors rose by students in learning activities, as follows:

a. Fluency, the indicators are:

- Ask many questions.

- Address with several answers when there are questions.

- Fluent in expressing ideas.

- Work faster and do more compared to other students.

- Able to quickly see the errors or lacks of an object or situation.

b. Flexibility, the indicators are:

- Provide a variety of unusual usages of an object.

- Provide a variety of interpretation of a figure, story or problem.

- Apply a concept or principle in a various way.

- Provide consideration towards a situation that is different to others'.

- In discussing a situation, always hold a different position or contradict to the majority of the group

- Upon given a problem, usually think about various solutions.
- Classify things by different cathegories

- Able to change the way of thinking.

c. Originality, the indicators are:

- Think about problems or things that are unthinkable by others.

- Question the old ways and try to think about the new ways.

- Prefers asymmetric in drawing or designing.

- Chose a way of thinking that is different to others.

- Find a new approach from stereotype.

- After reading or listening ideas, work to find a new solution.

- Prefer to synthesize than to analyze something.

d. Elaboration, the indicators are:

- Find a deeper meaning towards an answer or solution with a detailed steps.

- Develop or enrich other's ideas.

- Try or test details to see the directions to be taken.

- Have a strong sense of beauty therefore unsatisfied with empty or simple appearances.

- Add lines, colors, details (parts) towards own's fogures or other's.

Henriksen [6] in his dissertation research found 5 key approaches used by teachers who have were The Teacher of the Year Award winners in applying creative learning, namely:

- Connect teachers interests/hobbies with the learning

- Relate the lesson to daily real life

- Train and accustomize creative thinking pattern

- Appreciate collaboration to raise creative ideas

- Take intellectuality risks by trying new approaches

Hicks [2], revealed 5 ways to present creativity in the classroom with 5 ways, namely:

- Do not limit tasks in just a single format, give students the freedom to complete their tasks in a more free way

- Allocate special time for creativity events, for example $20 \%$ of studying time (as is applied in many modern companies)

- Use information technology for students' tasks

- Occasionally use properties or unusual learning materials

- Encourage discussions activity

To make learners who have the skills of creative thinking requires creative lecturers as well, resulting in a synergistic relationship that qualified learning activities will occur.

\section{LEARNING MEDIA COURSE}

One of the curriculum on the Culinary Education Study Program is learning media course [7]. In the Learning Media course, it presents material understanding, benefits, and kinds, characteristics of learning media and criteria in choosing learning media and designing and using learning media in Culinary learning. The learning achievement of the subject is to understand the understanding, the benefits, the kinds, the characteristics of learning media and able to 
choose, design and use various media in the Culinary learning. The material presented in the course, besides in form of theories, there are also practices to make learning media. The learning activities conducted all this time are in presentations and discussions. Students present about various learning media as well as their characteristics and practices of making learning media in groups.

Learning media is initially considered as a tool to assist educators in teaching activities with the intention of providing more concrete experiences, motivate and enhance the absorption and memory of students in learning, thus accelerating the learning process and assist students in an effort to understand the material presented. It is very important that teachers use instructional media in the learning activities in the classroom. In the learning media course, students as prospective teachers learn to understand about learning media to the extent of designing and using it.

\section{DISCUSSION}

Material delivery to the learners is very important. No matter how good is the material to achieve the goal, if it is not delivered correctly then the result will not be maximum, therefore it requires learning media. Learning media is a messenger technology that can be utilized for learning purposes so that the material can be received well by learners. Hence, the position of learning media in learning activities is essential.

In facing the industrial revolution 4.0, it will requires teachers who have the ability to communicate well, critical and creative thinking in the learning activities so that later learners who are taught will have the creative thinking skill. LPTK as one of the institutions that produces prospective teachers who have creative thinking skills. Learning activities should always and always be improved in its process. One of the support is in designing and using learning media. Creative teachers will use instructional media that can motivate learners to think creatively as well.

Hick [2] revealed that the ways to promote creativity in the learning activities, one of them, is by providing format flexibility for students to complete the task and using information technology in student's tasks. Meanwhile, according to Henriken, one of them is by connecting lessons with daily life.

The Learning Media Course is one of the courses contained in the curriculum. It aims to achieve the students' understanding about learning media to the extent of designing and using it. In addition, the learning activities are designed to improve students' creative thinking skills. Creative thinking skills can be traversed by integrating subjects with each other in learning activities. What is meant by integrated learning activities is the management of learning that links the courses with one another. Students will have the knowledge and skills intact, so that learning becomes meaningful for the students. Silberman [8] stated that people intend to forget what they heard. One of the reasons is the difference of fastness between the spoken with the ability to listen. Moreover, if the students seriously listen to the teacher or lecturer, they can get only a half of the speech. Through some strategies, the students' potential can be optimized. People can use the potential of thinking and the emotional the achieved the goal.
In the learning activity of learning media course, students are divided into small groups consisting of $3-5$ students. The learning media created is in accordance with the material in other selected courses. During the process of presentation and discussion, it is documented to record the learning activities by using the media that has been designed, to measure the success in its making and bringing the learning media that is chosen in accordance with the indicator of creative thinking skills.

It produces students who will be more familiar with the usefulness of learning media and find out whether or not the media created to deliver the material has been able to motivate and improve the skills of creative thinking with indicators of smoothly thinking that is with the audiences who ask many questions, can also answer with various alternative answers, then can provide ideas. In flexible thinking skills for example, it can solve a problem in different ways. In the original thinking skill, among others, will find a new way of settlement after hearing the ideas. Then on elaboration, by listening to their peer's opinions or ideas, students will be able to develop it into more detailed ideas.

Presentation results are discussed during the Learning Media Course meeting. When the created learning media cannot motivate students to think creatively, then the learning media is improved and used for further material presentation. Learning activities which are undertaken by integrating the courses, in addition to the understanding of learning media materials and the use of learning media, these can also motivate and improve creative thinking skills and also improve learning outcomes in other subjects. The results of research conducted by Ermaita et al [9], about the use of learning media to improve the skills of creative thinking, creative thinking skills in cycle 1 has the amount of $60.71 \%$ to $88.4 \%$ in cycle 3 . This shows an increase in creative thinking skills in students by using crossword puzzle learning media. In another study by Febriana Istiqomah et al [10], it was produced the average value of creative thinking skills in the experimental class is greater than in the control class with $t$ count of 3.853 and $t$ table of 1.671. It is concluded that media gives effect to the improvement of creative thinking skills on students. This is in line with what Ken Robinson reveals that the real mover grows and increases creativity is the desire to discover and passion on the job itself. When students are motivated to learn, they naturally acquire the skills they need to get the job done. Their mastery grows as their creative ambitions grow.

Learning media that can cause or motivate creative thinking will be able to make learners to become graduates who are ready to face the revolution 4.0. Students will be trained in designing and using learning media that can improve creative thinking skills. The graduates of Culinary Education Study Program will be ready to join SM3T and PPG programs, which will become a professional teacher. They are able to educate well wherever they will be placed, able to present creative thinking skills in learning activities with the learning media used. In turn, this gives birth to graduates who can face challenges and solve problems with their creativity. 


\section{CONCLUSION}

The era of industrial revolution 4.0 requires teachers who have good communication skills and creative thinking skills. Learning activities are very important in presenting activities that can motivate and enhance creative thinking skills.

In the learning activities of Learning Media course integrated with other courses. The learning activity model used is learning media made by students as a task used for material presentation in other courses. Success in carrying out the task that is the designed and used learning media can motivate and improve the skills of creative thinking with indicators of smoothly, flexibly, and originally, and ellaboratively thinking skills. Presentation activities are documented according to indicators of creative thinking skills. Presentation results are then discussed at the Learning Media course lecture. If the results are not satisfactory then the instructional media made needs to be repaired again. This model of learning activities will motivate and improve the creative thinking skills of students as prospective teachers.

Things achieved by using this learning activity model are the understanding and skills of making and using media will be achieved, creative thinking skill will be present in learning activity with instructional media that is used, and help the achievement of learning objectives of other courses taken. In turn, it will produce prospective teachers who have an excellent image that can face and solve the problem of classroom learning in the age of industrial revolution 4.0.

\section{REFERENCES}

[1] D. Starbuck, Creative Teaching: Getting It Right. Continuum International Publishing Group. London, 2006.

[2] K. Hicks, Why creativity in the classroom matters more than ever. Why Creativity in the Classroom Matters More Than Ever. Eududemic: Connecting Education \& Technology, 2015.

[3] U. Munandar, Kreativitas dan Keberbakatan. Jakarta: Gramedia Pustaka Utama. 1999.

[4] N. S. Sukmadinata, Kurikulum dan Pembelajaran Kompentensi. Bandung, 2004.

[5] J. Akhmad, Berfikir Kreatif Dalam Kemampuan Komunikasi Matematika. In Proceeding Seminar Nasional Matematika dan Pendidikan Matematika, 2009.

[6] D. Henriksen, We teach who we are: Creativity and trans$\neg$ disciplinary thinking in the practices of accomplished teachers. (Doctoral Dissertation). Retrieved from ProQuest Dissertations and Theses. (3489807), 2011.

[7] Culinary Education Program, Curriculum. Semarang: UNNES. 2015.

[8] M. E, Silberman, Active Learning: 101 Strategi Pembelajaran Aktif (terjemahan). Bandung: Nuansa, 2006.

[9] Ermaita, et al. Penggunaan Media Pembelajaran Crossword Puzzle Untuk Meningkatkan Keterampilan Berpikir Kreatif Siswa. Jurnal Studi Sosial Vol 4, No 1 p. 81-89, 2016.

[10] F, Istiqomah, A, Widiyatmoko, IU, Wusqo. Pengaruh Media Kokami terhadap Keterampilan Berpikir Kreatif dan Aktivitas Belajar Tema Bahan Kimia. Unnes Science Education Journal. 2016 Sep 11;5(2). 